\title{
Analisis Keragaan Cabai Rawit Merah (Capsicum frutescens ) Lokal Asal Kediri dan Jember
}

\section{Performance Analysis of Local Chili (Capsicum frutescens) Origin Kediri and Jember}

\author{
Nanda Chesaria, Sobir ${ }^{*}$ dan Muhamad Syukur
}

Departemen Agronomi dan Hortikultura, Fakultas Pertanian, Institut Pertanian Bogor

(Bogor Agricultural University), Jalan Meranti, Kampus IPB Darmaga, Bogor 16680, Indonesia

Telp. \& Faks. 0251-8629353 e-mail: agronipb@indo.net.id

*Penulis untuk korespondensi : sobir@ipb.ac.id

Disetujui 20 Agustus 2018 / Published online 3 September 2018

\begin{abstract}
The diversity of pepper production results is in addition caused by environmental influences, as well as the diverse genotype effects. The use of hybrid seeds (which has uniform gen) by farmers is still low and requires plant breeders to start thinking of assembling a local genotype that is resistant to certain environments. Exploration needs to be done to expand the utilization of local germplasm. The characterization of the fifteen local accessions from Kediri and Jember was conducted to obtain at least one superior character that is equal to or better than the strains and varieties of the comparative chili. The study was conducted from November 2016 to May 2017 at IPB's Experiment Garden Pasir Kuda and Plant Breeding Laboratory of Agronomy and Horticulture Department, Faculty of Agriculture, IPB, Bogor. The experimental design used was the Randomized Group Design and tested further with Tukey's Honestly Significant Difference (HSD). The genetic material that is tested consisted of 15 accessions (CR1, CR2, CR 3, CR 8, CR 9, CR 10, CR11, CR12, CR13, CR14, and CR15), 3 strains collections of Genetics and Plant Breeding Laboratory Department of Agronomy and Horticulture IPB (Bonita, F4321295285, F3321290), and 1 varieties of commercial hybrids for comparison (Taruna). The results showed that the effect of genotype had significant effect on almost all parameters observed, except the weight of 100 seeds. The result from correlation analysis showed that grain yield significantly with flowering periode, harvest periode, the number of fruit, and fruit weight per plant, but the weight per fruit with the weight of fruit per plant has positive correlation. Based on the value analysis of Bonita, Taruna, CR14, CR3, and CR8 varieties have the advantage of good yield potential compared to other genotypes.
\end{abstract}

Keywords: characterization, chili accession, qualitative character, quanitative character, and yield potential

\section{ABSTRAK}

Keberagaman hasil produksi cabai selain disebabkan oleh pengaruh lingkungan, juga karena pengaruh genotipe yang beragam. Penggunaan benih hibrida (sifat seragam) oleh petani masih rendah dan mengharuskan pemulia tanaman untuk memanfaatkan genotipe lokal yang relatif sergam dan tahan pada lingkungan tertentu. Eksplorasi perlu dilakukan untuk memperluas pemanfaatan plasma nutfah lokal. Tujuan dari penelitian ini adalah untuk mengkarakterisasi lima belas aksesi lokal asal Kediri dan Jember dan memperoleh setidaknya satu karakter unggul yang sama atau lebih baik dari galur dan varietas cabai rawit pembandingnya. Penelitian dilaksanakan dari November 2016 hingga Mei 2017 di Kebun Percobaan IPB Pasir Kuda dan Laboratorium Pemuliaan Tanaman Departemen Agronomi dan Hortikultura, Fakultas Pertanian, IPB, Bogor. Rancangan percobaan yang digunakan adalah Rancangan Kelompok Teracak Lengkap (RKLT) dan diuji lanjut dengan Tukey Beda Nyata Jujur (TABEL). Bahan genertik yang diuji terdiri atas 15 aksesi (CR1, CR2, CR3, CR4, CR5, CR6, CR7, CR8, CR9, CR10, CR11, CR12, CR13, CR14, dan CR15), 3 galur cabai koleksi Laboratorium Genetika dan Pemuliaan Tanaman Departemen Agronomi dan Hortikultura IPB (Bonita, F4321295285, F3321290), dan 1 varietas hibrida komersial sebagai pembanding (Varietas Taruna). Hasil penelitian menunjukkan bahwa genotipe berpengaruh nyata pada hampir seluruh parameter yang diamati, kecuali bobot 100 butir. Hasil analisis korelasi menunjukkan umur berbunga dan umur panen bernilai positif, umur panen dengan jumlah buah dan bobot buah per tanaman bernilai positif, dan bobot per buah dengan bobot buah per tanaman bernilai positif. Berdasarkan nilai analisis ragam, Bonita, Taruna, CR14, CR3, dan CR8 memiliki keunggulan potensi hasil yang cukup baik dibanding genotipe lain.

Kata kunci : aksesi cabai rawit, karakterisasi, karakter kualitatif, karakter kuantitatif, potensi hasil 


\section{PENDAHULUAN}

Cabai rawit (Capsicum frutescens.) masuk ke dalam famili solanaceae. Salah satu yang membedakan cabai jenis frutescen dengan jenis yang lain adalah bunganya yang berarna putih kehijauan dan cenderung menyerbuk sendiri (self polination), namun tidak menutup kemungkinan untuk menyerbuk silang (Undang et al., 2015). Kebutuhan cabai rawit terus meningkat, karena penggunaannya tidak hanya di sektor pangan, tetapi juga sebagai bahan baku obat dan kosmetik karena kandungan capsaicin di dalamnya (Koassi, 2012). Selain itu, cabai rawit juga memiliki rasa yang lebih pedas dan memiliki potensi hasil yang lebih tinggi karena dapat hidup menahun (Undang et al., 2015). Salah satu kekurangan dari tanaman ini adalah usia panen yang lama yaitu mencapai 56 bulan setelah pindah tanam.

Produksi cabai rawit cenderung mengalami peningkatan sejak tahun 1980-2014 seiring dengan bertambahnya luas panen, namun penyediannya cenderung berfluktuatif karena waktu puncak panen yang tidak teratur setiap tahunnya (Pusdatin, 2015). Fluktuasi ini menyebabkan harga jual cabai dipasaran tidak stabil dan menjadikan cabai sebagai tiga besar komoditas penyebab inflasi di Indonesia (BI, 2013). Fluktuasi produksi cabai disebabkan oleh musim tanam dan faktor lingkungan yang beragam. Selain itu, sering ditemukan bentuk buah yang beragam sehingga mempengaruhi bobotnya. Gen dan faktor lingkungan sangat berpengaruh terhadap bentuk buah, bobot buah, dan usia panen dari suatu tanaman. Keragaman genetik yang terbilang cukup tinggi ini diduga menjadi salah satu faktor penyebab produksi yang berfluktuatif.

Pemuliaan tanaman menjadi salah satu strategi untuk menghasilkan varietas unggul dengan potensi hasil yang tinggi. Varietas hibrida merupakan salah satu hasil pemuliaan tanaman dan menjadi salah satu pilihan solusi permasalahan produksi cabai, namun karena perlu pemeliharaan yang intensif, banyak petani memilih untuk menggunakan benih hasil perbanyakannya sendiri. Penggunaan genotipe lokal diharapkan dapat dimanfaatkan sebagai sumber genetik yang unggul dan mudah diperoleh. Eksplorasi terhadap tanaman cabai sudah banyak dilakukan dimulai dari introduksi genotipe lokal hingga genotipe dari luar negri (Syukur et al., 2012). Eksplorasi terhadap genotipe lokal diharapkan dapat meningkatkan pemanfaatan plasma nutfah lokal dan menghasilkan produk unggul yang sesuai dengan iklim lokal Indonesia. Tujuan dari penelitian ini adalah mengkarakterisasi 15 aksesi lokal asal Jember dan Kediri dan menemukan sekurangnya satu karakter unggul lebih dari atau sama dengan genotipe pembanding yang digunakan.

\section{BAHAN DAN METODE}

Penelitian dilakukan di Kebun Percobaan IPB Pasir Kuda dan Laboratorium Pemuliaan Tanaman Departemen Agronomi dan Hortikultura, Fakultas Pertanian, IPB, Bogor pada bulan November 2016 hingga Mei 2017. Bahan genetik yang digunakan berupa 15 aksesi cabai rawit (CR1, CR2, CR3, CR4, CR5, CR6, CR7, CR8, CR9, CR10, CR11, CR12, CR13, CR14, dan CR15) asal Kediri dan Jember dan genotipe pembanding yang terdiri atas 3 galur cabai koleksi Laboratorium Genetika dan Pemuliaan Tanaman Departemen Agronomi dan Hortikultura IPB (Bonita, F4321295285, F3321290) dan 1 varietas hibrida komersial (Varietas Taruna). Penelitian ini menggunakan model Rancangan Kelompok Lengkap Teracak (RKTL) faktor tunggal (Gomez dan Gomez, 2007) dengan satu faktor tunggal. Masing-masing genotipe dibuat tiga ulangan, sehingga terdapat 57 satuan percobaan. Penelitian dimulai dengan penyemaian benih hingga 5 MSS (Minggu Setelah Semai). Pindah tanam bibit dilakukan setelah bibit memiliki 4-5 daun sejati. Total bedeng yang digunakan adalah 57 bedeng dengan luas satu bedeng yang digunakan adalah $6 \mathrm{~m}^{2}$ dan jarak tanam $(50 \times 50) \mathrm{cm}$. Pemeliharaan dilakukan setiap minggu yang terdiri atas penyiraman, pemupukan, pewiwilan tunas air, pengendalian gulma, hama, dan penyakit. Pengamatan dilakukan pada sepuluh tanaman contoh yang dipilih secara acak pada masingmasing ulangan. Penentuan peubah mengikuti panduan International Plant Genetic Resources Institute (1995) yang terdiri atas peubah kuantitatif dan kualitatif.

Peubah kuantitatif yang diamati meliputi, tinggi tanaman $(\mathrm{cm})$; diameter batang $(\mathrm{cm})$; umur berbunga (HST); umur panen (HST), panjang buah $(\mathrm{cm})$; lebar buah $(\mathrm{mm})$; bobot per buah $(\mathrm{g})$; jumlah buah per tanaman; bobot buah per tanaman (g); jumlah biji per buah; bobot 100 biji (g); dan jumlah lokul. Peubah kualitatif yang diamati meliputi, warna batang muda; warna nodul ; bentuk batang; tipe pertumbuhan tanaman; warna daun; bentuk daun; warna mahkota; warna anther; posisi stigma; warna buah muda; warna buah matang; bentuk buah; bentuk pangkal buah; penampilan permukaan buah; bentuk potongan melintang buah; dan bentuk pedikel.

Data kuantitatif yang diperoleh dianalisis dengan menggunakan uji-F dan diuji lanjut dengan metode Tukey's Honestly Significant Difference (HSD/BNJ). Data kualitatif ditentukan 
sesuai pedoman deskripsi IPGRI (International Plant Genetic Resources Institute) (1995) dan diambil berdasarkan modus (data sebaran terbanyak). Hubungan korelasi antar peubah dianalisis dengan menggunakan analisis korelasi Pearson untuk melihat derajat keeratan diantara peubahnya. Analisis gerombol dilakukan untuk melihat kemiripan antar genotipe.

\section{HASIL DAN PEMBAHASAN}

\section{Karakter kualitatif}

Tabel 1. Keragaman karakter kualitatif batang, tipe pertumbuhan, dan daun

\begin{tabular}{|c|c|c|c|c|c|c|}
\hline Genotipe & Warna Batang Muda & $\begin{array}{l}\text { Warna } \\
\text { Nodul }\end{array}$ & Bentuk Batang & Tipe Pertumbuhan & Warna Daun & $\begin{array}{c}\text { Bentuk } \\
\text { Daun }\end{array}$ \\
\hline CR1 & Hijau & Hijau & Bersiku & Tegak & Hijau & Deltoid \\
\hline CR2 & Hijau & Hijau & Bersiku & Tegak & Hijau & Deltoid \\
\hline CR3 & Hijau & Hijau & Bersiku & Tegak & Hijau & Deltoid \\
\hline CR4 & Hijau & Hijau & Silindris & Tegak & Hijau & Deltoid \\
\hline CR5 & Hijau & Hijau & Bersiku & Tegak & Hijau Terang & Deltoid \\
\hline CR6 & Hijau + Strip Ungu & Hijau & Silindris & Tegak & Hijau Terang & Ovate \\
\hline CR7 & Hijau & Hijau & Silindris & Semi Merunduk & Hijau & Deltoid \\
\hline CR8 & Hijau & Hijau & Bersiku & Tegak & Hijau & Deltoid \\
\hline CR9 & Hijau & Hijau & Bersiku & Tegak & Hijau & Deltoid \\
\hline CR10 & Hijau & Hijau & Silindris & Semi Merunduk & Hijau Terang & Ovate \\
\hline CR11 & Hijau & Hijau & Bersiku & Tegak & Hijau & Deltoid \\
\hline CR12 & Hijau & Hijau & Bersiku & Tegak & Hijau & Deltoid \\
\hline CR13 & Hijau & Hijau & Bersiku & Semi Merunduk & Hijau & Deltoid \\
\hline CR14 & Hijau & Hijau & Silindris & Semi Merunduk & Hijau & Deltoid \\
\hline CR15 & Hijau & Hijau & Bersiku & Semi Merunduk & Hijau & Deltoid \\
\hline F3 & Hijau & Hijau & Bersiku & Semi Merunduk & Hijau & Deltoid \\
\hline $\mathrm{F} 4$ & Hijau + Strip Ungu & Hijau & Bersiku & Semi Merunduk & Hijau & Deltoid \\
\hline BONITA & Hijau & Hijau & Bersiku & Semi Merunduk & Hijau & Deltoid \\
\hline TARUNA & Hijau & Hijau & Bersiku & Semi Merunduk & Hijau & Deltoid \\
\hline
\end{tabular}

Karakter kualitatif batang dan daun (Tabel 1) yang diamati meliputi warna batang muda, warna nodul, bentuk batang, tipe pertumbuhan, warna daun, dan bentuk daun. Warna batang muda diamati pada tanaman muda yang berusia 5 MSS (Minggu Setelah Semai). Keragaman terjadi pada aksesi CR6 dan galur F4 yang memiliki strip ungu pada batangnya, sedangkan untuk genotipe lainnya memiliki warna hijau. Keberadaan strip ungu pada batang menghilang setelah tanaman beradaptasi di lahan. Bentuk batang pada umumnya bersiku, kecuali CR4, CR6, CR7,CR10, CR14, dan CR15 yang memiliki bentuk batang mendekati silindris. Karakter bentuk batang diamati pada batang utama (IPGRI, 1995). Penentuan bentuk batang bersifat cukup subjektif.

Bentuk daun cabai menurut IPGRI (1995) terdiri atas tiga bentuk, yaitu deltoid, ovate, dan lanceolet. Bentuk daun pada 19 genotipe cabai rawit yang teramati 17 diantaranya berbentuk deltoid (bentuk agak bulat, meruncing di salah satu ujungnya, dan rata pada bagian yang
Karakter kualitatif merupakan karakter yang diukur berdasarkan gejala yag ditunjukkan. Menurut Syukur et al. (2012) karakter kualitatif merupakan karakter yang dikendalikan oleh gen sederhana dan tidak atau dikit sekali dipengaruhi oleh lingkungan. Karakter kualitatif diuji pada 19 genotipe cabai rawit yang meliputi empat bagian tanaman, yaitu batang, daun, bunga, dan buah. Penentuan karakter kualitatif pada penelitian ini mengikuti deskripsi IPGRI (1995) dan ditentukan berdasarkan sebaran modus atau nilai terbanyak. menempel pada tangkai daun) dan dua genotipe lainnya, aksesi CR6 dan CR10, memiliki bentuk daun yang cenderung ovate (bentuk daun agak oval). Tipe pertumuhan tanaman diamati pada tanaman dewasa. Menurut IPGRI (1995) ada tiga bentuk tipe pertumbuhan tanaman cabai, yaitu merunduk (prostrate), semi merunduk (intermediate), dan tegak (erect). Hasil pengamatan pada 19 genotipe menunjukkan 10 genotipe bertipe tegak dan 9 lainnya bertipe semi merunduk (Tabel 1). Penentuan tipe pertumbuhan diamati berdasarkan alur percabangan dari titik dikotomous (titik percabangan utama pada tanaman cabai). Tipe pertumbuhan semi merunduk menunjukkan bentuk percabangan tajuk yang melebar diikuti dengan percabangan keatas dan kesamping, sedangkan pada percabangan tipe tegak konstan tumbuh keatas. Tanaman dengan tipe tajuk tegak pada umumnya memiliki tinggi tanaman yang lebih tinggi dibanding tipe lain. 
Tabel 2. Keragaman karakter kualitatif bunga

\begin{tabular}{lcccc}
\hline Genotipe & Posisi Bunga & Warna Mahkota & Warna Anther & Posisi Stigma \\
\hline CR1 & Tegak & Putih Kehijauan & Biru pucat keunguan & Keluar \\
CR2 & Tegak & Putih Kehijauan & Biru pucat keunguan & Keluar \\
CR3 & Tegak & Putih Kehijauan & Biru pucat keunguan & Keluar \\
CR4 & Tegak & Putih Kehijauan & Biru pucat keunguan & Keluar \\
CR5 & Tegak & Putih Kehijauan & Putih & Keluar \\
CR6 & Tegak & Putih Kehijauan & Keluar \\
CR7 & Tegak & Putih Kehijauan & Biru pucat keunguan & Keluar \\
CR8 & Tegak & Putih Kehijauan & Biru pucat keunguan & Keluar \\
CR9 & Tegak & Putih Kehijauan & Biru pucat keunguan & Keluar \\
CR10 & Tegak & Putih Kehijauan & Biru pucat keunguan & Keluar \\
CR11 & Tegak & Putih Kehijauan & Biru pucat keunguan & Keluar \\
CR12 & Tegak & Putih Kehijauan & Putih & Keluar \\
CR13 & Tegak & Putih Kehijauan & Biru pucat keunguan & Keluar \\
CR14 & Tegak & Putih Kehijauan & Biru pucat keunguan & Keluar \\
CR15 & Tegak & Putih Kehijauan & Biru pucat keunguan & Keluar \\
F3 & Tegak & Putih Kehijauan & Ungu & Keluar \\
F4 & Tegak & Putih Kehijauan & Biru pucat keunguan & Keluar \\
BONITA & Tegak & Putih Kehijauan & Biru pucat keunguan & Keluar \\
TARUNA & Tegak & Putih Kehijauan & Biru pucat keunguan & Keluar \\
\hline
\end{tabular}

Karakter kualitatif bunga yang diamati meliputi posisi bunga, warna mahkota bunga, warna anther, dan posisi stigma (Tabel 2). Kondisi umum karakter bunga dari 19 genotipe yang diuji menunjukkan persamaan di setiap karakter kecuali pada warna anther. Warna anther yang teramati diantaranya biru pucat keunguan, putih, dan ungu. Genotipe yang memiliki anther berwarna putih adalah aksesi CR5 dan CR12. Genotipe yang memiliki anther berwarna ungu adalah aksesi CR6 dan galur F3. Genotipe lainnya memiliki warna anther biru pucat-keunguan. Menurut IPGRI (1995) karakter warna anther diamati pada anther yang yang belum anthesis, sehingga pengamatan warna anther dilakukan pada bunga yang kuncup besar hingga baru mekar agar dapat memperoleh anther yang segar.

Tabel 3. Keragaman karakter kualitatif buah

\begin{tabular}{lcccc}
\hline Genotipe & Warna Buah Muda & Warna Buah Matang & Bentuk Buah & Bentuk Ujung Buah \\
\hline CR1 & Yellow-Green & Merah & Blocky & Cekung-Tumpul \\
CR2 & Yellow-Green & Merah & Triangular & Tumpul \\
CR3 & Yellow-Green & Merah Gelap & Blocky & Cekung \\
CR4 & Yellow-Green & Merah & Campanulate & Cekung-Tumpul \\
CR5 & Yellow-Green & Merah & Triangular & Cekung \\
CR6 & Yellow-Green & Merah & Elongate & Runcing \\
CR7 & Yellow-Green & Merah & Triangular & Tumpul \\
CR8 & Yellow-Green & Merah & Elongate & Runcing \\
CR9 & Yellow-Green & Merah & Triangular & Tumpul \\
CR10 & Yellow-Green & Merah Terang & Elongate & Runcing \\
CR11 & Yellow-Green & Merah & Triangular & Cembung \\
CR12 & Yellow-Green & Merah & Triangular & Cembung \\
CR13 & Yellow-Green & Merah & Triangular & Cembung \\
CR14 & Yellow-Green & Merah & Elongate & Runcing \\
CR15 & Yellow-Green & Merah & Elongate & Runcing \\
F3 & Yellow-Green & Merah & Elongate & Runcing \\
F4 & Yellow-Green & Merah Terang & Elongate & Runcing \\
BONITA & Yellow-Green & Merah & Triangular & Runcing \\
TARUNA & Yellow-Green & Merah & Triangular & Runcing \\
\hline
\end{tabular}


Tabel 4. Keragaman karakter kualitatif buah

\begin{tabular}{lccc}
\hline Genotipe & Penampilan Permukaan & Bentuk Penampang Melintang & Bentuk Penempelan pedicle \\
\hline CR1 & Semi-Keriput & Semi Kerut & Tumpul \\
CR2 & Semi-Keriput & Sedikit Kerut & Runcing \\
CR3 & Keriput & Kerut & Runcing \\
CR4 & Keriput & Kerut & Tumpul \\
CR5 & Keriput & Kerut & Tumpul \\
CR6 & Keriput & Kerut & Tumpul \\
CR7 & Semi-Keriput & Sedikit Kerut & Tumpul \\
CR8 & Semi-Keriput & Sedikit Kerut & Tumpul \\
CR9 & Semi-Keriput & Semi Kerut & Tumpul \\
CR10 & Semi-Keriput & Sedikit Kerut & Runcing \\
CR11 & Semi-Keriput & Semi Kerut & Tumpul \\
CR12 & Keriput & Kerut & Tumpul \\
CR13 & Semi-Keriput & Semi Kerut & Tumpul \\
CR14 & Semi-Keriput & Semi Kerut & Tumpul \\
CR15 & Semi-Keriput & Semi Kerut & Tumpul \\
F3 & Semi-Keriput & Sedikit Kerut & Tumpul \\
F4 & Mulus & Sedikit Kerut & Tumpul \\
BONITA & Semi-Keriput & Semi Kerut & Runcing \\
TARUNA & Mulus & Sedikit Kerut & Runcing \\
\hline
\end{tabular}

Karakter kualitatif buah meliputi warna buah muda, warna buah matang, bentuk buah, bentuk ujung buah (Tabel 3), penampilan permukaan buah, bentuk penampang melintang buah, bentuk penempelan pedicle (tangkai buah) (Tabel 4). Karakter buah muda diamati menggunankan RHSCC (Royal Horticulture Society Colour Chart). Pengamatan terhadap 19 genotipe menunjukkan bahwa warna buah muda relatif seragam berwarna hijau kuning. Karakter warna buah matang pada 19 genotipe menunjukkan keseragaman berwarna merah. Pengamantan dilakukan secara visual tanpa alat bantu. Karakter bentuk buah yang teramati pada 19 genotipe adalah blocky (CR1 dan CR3), triangular (CR2, CR5, CR7, CR9, CR11, CR12, CR13, Bonita, dan Taruna), campanulate (CR4), dan elongate (CR6, CR8, CR10,CR14, CR15, F3, dan F4). Bentuk buah cukup mempengaruhi bentuk ujung buah. Buah dengan bentuk blocky cenderung memiliki ujung buah cekung (tidak lancip) dan bentuk triangled dan elongate memiliki unjung yang lancip.
Karakter permukaan buah menurut IPGRI (1995) terdiri atas mulus, semi-keriput, keriput. Karakter penampilan permukaan buah dari sembilan belas genotipe pada umunya bertipe semi-keriput, kecuali Taruna dan F4 yang memiliki permukaan mulus, dan tipe permukaan keriput yang dimiliki oleh CR3, CR4, CR5, C6, dan CR12 (Tabel 4). Bentuk penampang melintang terdiri atas tipe sedikit kerut, semi kerut, dan kerut. Penampang melintang buah dipengaruhi oleh penampilan permukaannya.

\section{Karakter Kuantitatif}

Karakter kuantitatif merupakan karakter yang dipengaruhi oleh banyak gen yang masingmasing memiliki pengaruh kecil pada karakter tersebut (Syukur et al., 2012). Karakter kuantitatif sangat dipengaruhi oleh lingkungan (Acquaah, 2007). Nilai yang diperoleh dari data kuantitatif kemudian diuji-F untuk melihat pengaruh genotipe terhadap parameter yang diamati.

Tabel 5. Analisis ragam karakter kuantitatif genotipe cabai

\begin{tabular}{|c|c|c|c|c|}
\hline Peubah & Kisaran & Genotipe & F Hitung & KK $(\%)$ \\
\hline Umur Berbunga (HST) & $35,00-80,00$ & 172,75 & $4,24 * *$ & 13,61 \\
\hline Umur Panen (HST) & $93,00-135,00$ & 373,33 & $11,22 * *$ & 5,12 \\
\hline Tinggi Tanaman $(\mathrm{cm})$ & $53,62-113,00$ & 452,06 & $10,45^{* *}$ & 7,99 \\
\hline Diameter batang (mm) & $8,93-16,00$ & 4,99 & $3,53 * *$ & 9,56 \\
\hline Panjang buah $(\mathrm{cm})$ & $2,69-6,31$ & 1,98 & $20,85^{* *}$ & 8,04 \\
\hline Diameter buah (mm) & $6,91-17,40$ & 25,06 & $20,11 * *$ & 9,49 \\
\hline Bobot buah $(\mathrm{g})$ & $0,97-4,06$ & 1,66 & $10,00 * *$ & 20,39 \\
\hline Jumlah buah/tanaman & $21,50-297,40$ & 10428,00 & $9,99 * *$ & 28,35 \\
\hline Bobot buah/tanaman (g) & $20,91-368,51$ & 23674,93 & $16,32 * *$ & 23,67 \\
\hline Jumlah biji/buah & $23,00-76,00$ & 395,57 & $14,14 * *$ & 11,89 \\
\hline Bobot 100 biji (g) & $0,32-1,46$ & 0,03 & $1,54 \mathrm{tn}$ & 24,93 \\
\hline Jumlah lokul & $2,00-4,00$ & 0,85 & $54,5 \times 1012 * *$ & 0,00 \\
\hline
\end{tabular}


Analisis ragam dilakukan pada sembilan belas genotipe dan memberikan hasil yang berbeda nyata hampir di setiap peubah, kecuali pada bobot 100 biji yang menunjukkan hasil tidak berbeda nyata (Tabel 5). Koefesien keragaman (KK) digunakan untuk menduga besar galat dan keragaman yang terjadi di lahan. Nilai KK 30\% pada kondisi lapang dianggap masih wajar karena kondisi lingkungan dapat berpengaruh pada karkater kuantitatif. Semakin kecil nilai KK, maka keragaman antar genotipe semakin kecil, begitupun sebaliknya.

Karakter kuantitatif umur berbunga memiliki kisaran 35-80 HST (Hari Setelah Tanam) (Tabel 5). Berdasarkan hasil uji lanjut BNJ, Bonita menunjukkan umur berbunga yang paling pendek dan tidak berbeda nyata dengan beberapa genotipe lainnya terutama aksesi CR14 dan CR8 (Tabel 6). Umur panen dari sembilan belas genotipe yang diuji memiliki kisaran 95-135 HST (Tabel 5). Nilai uji lanjut menunjukkan bahwa galur Bonita dan aksesi CR14 memiliki nilai terkecil atau umur panen tercepat diikuti dengan CR3,CR8, F4, F3, dan Taruna (Tabel 6).

Nilai tengah tinggi tanaman dari sembilan belas aksesi memiliki kisaran 54,61-113 cm. Hasil uji lanjut menunjukkan bahwa CR12 memiliki nilai tertinggi dan tidak berbeda nyata dengan aksesi CR3, CR6, dan Bonita. Nilai KT (kuadrat tengah) pada aksesi CR10 merupakan yang terendah. Nilai diameter batang tertinggi dimiliki oleh CR12 dan diikuti oleh CR1, CR2, CR6, dan CR7. Kisaran diameter batang dari sembilan belas genotipe adalah 8,93-16,00 mm. Jumlah lokul buah terbanyak dimiliki oleh CR1.

Tabel 6. Analisis uji lanjut karakter kuantitatif genotipe cabai

\begin{tabular}{|c|c|c|c|c|c|c|}
\hline Genotipe & UB (HST) & UP (HST) & TTn $(\mathrm{cm})$ & $\mathrm{DBt}(\mathrm{mm})$ & JBeB (butir) & JL (lokul) \\
\hline CR1 & 49,67 abe & $116,33 \mathrm{abc}$ & 88,20 b-e & $13,68 \mathrm{abc}$ & $56,2 \mathrm{~b}$ & $4 a$ \\
\hline CR2 & $53,67 \mathrm{abc}$ & $123,33 \mathrm{a}$ & 85,39 b-f & $13,85 \mathrm{abc}$ & $43,07 \mathrm{~b}-\mathrm{e}$ & $3 b$ \\
\hline CR3 & $42,67 \mathrm{bc}$ & $102,22 \mathrm{~cd}$ & $100,50 \mathrm{ab}$ & $11,97 \mathrm{abc}$ & $74,80 \mathrm{a}$ & $3 b$ \\
\hline CR4 & $47,67 \mathrm{abc}$ & $117,00 \mathrm{abc}$ & $76,33 \mathrm{c}-\mathrm{g}$ & $12,68 \mathrm{~b}-\mathrm{g}$ & $56,80 \mathrm{~b}$ & $2 c$ \\
\hline CR5 & $53,33 \mathrm{abc}$ & $116,33 \mathrm{abc}$ & 85,04 b-f & $12,83 \mathrm{~b}-\mathrm{g}$ & $35,03 \mathrm{def}$ & $2 c$ \\
\hline CR6 & $65,67 \mathrm{a}$ & $125,67 \mathrm{a}$ & $91,80 \mathrm{a}-\mathrm{d}$ & $13,47 \mathrm{abc}$ & $34,60 \mathrm{def}$ & $2 c$ \\
\hline CR7 & $45,00 \mathrm{bc}$ & $121,00 \mathrm{ab}$ & 81,19 b-f & $14,52 \mathrm{ab}$ & $37,50 \mathrm{c}-\mathrm{f}$ & $2 c$ \\
\hline CR8 & $40,33 \mathrm{c}$ & $97,67 \mathrm{~d}$ & $73,17 \mathrm{~d}-\mathrm{g}$ & $11,46 \mathrm{bc}$ & $49,33 \mathrm{~b}-\mathrm{e}$ & $2 c$ \\
\hline CR9 & $60,33 \mathrm{ab}$ & $123,33 \mathrm{a}$ & $85,23 \mathrm{~b}-\mathrm{f}$ & $11,26 \mathrm{bc}$ & $42,77 \mathrm{~b}-\mathrm{e}$ & $2 c$ \\
\hline CR10 & $48,67 \mathrm{abc}$ & $118,67 \mathrm{abc}$ & $57,14 \mathrm{~g}$ & $11,62 \mathrm{abc}$ & $24,07 \mathrm{f}$ & $2 c$ \\
\hline CR11 & $45,00 \mathrm{bc}$ & $125,67 \mathrm{a}$ & $66,00 \mathrm{fg}$ & $12,34 \mathrm{abc}$ & 32,23 ef & $2 c$ \\
\hline CR12 & $51,33 \mathrm{abc}$ & $123,33 \mathrm{a}$ & $109,07 \mathrm{a}$ & $15,24 \mathrm{a}$ & $50,00 \mathrm{bcd}$ & $2 c$ \\
\hline CR13 & $45,67 \mathrm{bc}$ & $116,33 \mathrm{abc}$ & $76,63 \mathrm{c}-\mathrm{g}$ & $10,57 \mathrm{c}$ & $41,33 \mathrm{~b}-\mathrm{e}$ & $2 c$ \\
\hline CR14 & $37,67 \mathrm{c}$ & $93,00 \mathrm{~d}$ & $78,49 \mathrm{c}-\mathrm{f}$ & $12,00 \mathrm{abc}$ & $53,06 \mathrm{bc}$ & $2 c$ \\
\hline CR15 & $44,00 \mathrm{bc}$ & $116,33 \mathrm{abc}$ & $69,75 \mathrm{efg}$ & $11,18 \mathrm{bc}$ & $40,90 \mathrm{~b}-\mathrm{e}$ & $2 c$ \\
\hline F3 & $42,67 \mathrm{bc}$ & $104,67 \mathrm{bcd}$ & $79,96 \mathrm{c}-\mathrm{f}$ & $12,84 \mathrm{abc}$ & $37,40 \mathrm{c}-\mathrm{f}$ & $2 c$ \\
\hline $\mathrm{F} 4$ & $39,33 \mathrm{c}$ & $102,33 \mathrm{~cd}$ & 87,46 b-e & 10,99 bc & 36,13 def & $2 c$ \\
\hline BONITA & $35,67 \mathrm{c}$ & $93,00 \mathrm{~d}$ & $96,33 \mathrm{abc}$ & $12,99 \mathrm{abc}$ & $54,97 \mathrm{~b}$ & $2 c$ \\
\hline TARUNA & $42,33 \mathrm{bc}$ & $102,33 \mathrm{~cd}$ & $74,55 \mathrm{~d}-\mathrm{g}$ & $11,04 \mathrm{bc}$ & $43,50 \mathrm{~b}-\mathrm{e}$ & $2 c$ \\
\hline
\end{tabular}

Nilai tengah panjang buah memiliki kisaran 2,69-6,31 cm (Tabel 5). Berdasarkan hasil uji lanjut, aksesi CR14 merupakan buah yang paling panjang, sedangkan CR4 memiliki nilai yang paling rendah (Tabel 7). Karakter diameter buah dari sembilan belas genotipe memiliki kisaran 0,81-1,69 mm. Nilai diameter buah tertinggi dimiliki oleh CR3. Bobot buah tertinggi juga dimiliki oleh CR3 dan diikuti oleh CR 8, CR14, dan Bonita. Bobot 100 biji memiliki nilai uji $F$ yang tidak nyata, sehingga genotipe dianggap tidak berpengaruh nyata terhadap peubah ini. Beberapa genotipe mengalami keterlambatan umur panen dibanding genotipe lainnya sehingga mempengaruhi jumlah buah per tanaman. Berdasarkan uji lanjut, genotipe yang memiliki jumlah buah per tanaman terbesar dimiliki oleh Bonita diikuti oleh Taruna, CR8, dan CR14. Bobot buah per tanaman yang teramati memiliki kisaran 20,91-368,51 g (Tabel 5). Bobot buah per tanaman terbesar dimiliki oleh aksesi CR3 dan diikuti oleh CR8, CR14, dan Bonita (Tabel 7). 
Tabel 7. Analisis uji lanjut karakter kuantitatif genotipe cabai

\begin{tabular}{|c|c|c|c|c|c|}
\hline Genotipe & Dbu (mm) & Bbu (g) & Pbu $(\mathrm{cm})$ & JBT (buah) & BBT (g) \\
\hline CR1 & $13,46 \mathrm{~cd}$ & $2,07 \mathrm{~b}-\mathrm{f}$ & 3,05 ef & 118,76 b-f & $185,00 \mathrm{bcd}$ \\
\hline CR2 & $13,59 \mathrm{bcd}$ & $2,27 \mathrm{~b}-\mathrm{e}$ & $3,55 \mathrm{~b}-\mathrm{f}$ & 56,86 ef & 119,97 cde \\
\hline CR3 & $17,40 \mathrm{a}$ & $4,06 \mathrm{a}$ & $3,91 \mathrm{~b}-\mathrm{e}$ & 153,97 a-e & $332,96 \mathrm{a}$ \\
\hline CR4 & $14,38 \mathrm{abc}$ & $1,81 \mathrm{~b}-\mathrm{f}$ & $2,77 \mathrm{f}$ & 94,65 def & $127,75 \mathrm{cde}$ \\
\hline CR5 & $13,29 \mathrm{~cd}$ & $1,89 \mathrm{~b}-\mathrm{f}$ & $3,47 \mathrm{~b}-\mathrm{f}$ & $99,70 \mathrm{c}-\mathrm{f}$ & 136,62 cde \\
\hline CR6 & 9,36 e-h & $1,69 \mathrm{c}-\mathrm{f}$ & $4,36 \mathrm{~b}$ & $50,48 \mathrm{f}$ & $63,54 \mathrm{e}$ \\
\hline CR7 & $11,77 \mathrm{c}-\mathrm{f}$ & 1,45 def & $3,56 \mathrm{~b}-\mathrm{f}$ & 85,97 def & $109,41 \mathrm{cde}$ \\
\hline CR8 & $10,47 \mathrm{~d}-\mathrm{g}$ & $2,31 \mathrm{~b}-\mathrm{e}$ & $5,45 \mathrm{a}$ & $201,80 \mathrm{ab}$ & $305,04 \mathrm{a}$ \\
\hline CR9 & $11,35 \mathrm{c}-\mathrm{g}$ & $1,93 \mathrm{~b}-\mathrm{f}$ & 3,44 b-f & 57,30 ef & $94,65 \mathrm{de}$ \\
\hline CR10 & $6,91 \mathrm{~h}$ & $0,97 \mathrm{f}$ & $4,31 \mathrm{bc}$ & $61,87 \mathrm{def}$ & $56,12 \mathrm{e}$ \\
\hline CR11 & 12,19 cde & $1,74 \mathrm{c}-\mathrm{f}$ & $3,37 \mathrm{c}-\mathrm{f}$ & 56,35 ef & $89,74 \mathrm{de}$ \\
\hline CR12 & $17,03 \mathrm{ab}$ & $3,04 \mathrm{ab}$ & 3,74 b-e & 63,96 def & $144,20 \mathrm{cde}$ \\
\hline CR13 & 11,98 cde & $1,99 \mathrm{~b}-\mathrm{f}$ & $3,35 \mathrm{~d}-\mathrm{f}$ & $67,56 \mathrm{def}$ & $121,50 \mathrm{cde}$ \\
\hline CR14 & $10,69 \mathrm{~d}-\mathrm{g}$ & $2,75 \mathrm{bc}$ & $6,12 \mathrm{a}$ & $196,57 \mathrm{abc}$ & 308,06 a \\
\hline CR15 & $8,38 \mathrm{fgh}$ & 1,08 ef & $3,60 \mathrm{~b}-\mathrm{f}$ & $111,34 \mathrm{~b}-\mathrm{f}$ & $90,17 \mathrm{de}$ \\
\hline F3 & $8,02 \mathrm{gh}$ & $1,56 \mathrm{c}-\mathrm{f}$ & $4,19 \mathrm{bcd}$ & $159,73 \mathrm{a}-\mathrm{d}$ & $173,13 \mathrm{cde}$ \\
\hline $\mathrm{F} 4$ & $8,18 \mathrm{gh}$ & 1,10 ef & 3,03 ef & 94,20 def & $85,14 \mathrm{de}$ \\
\hline BONITA & $13,74 \mathrm{bcd}$ & $2,62 \mathrm{bcd}$ & $4,06 \mathrm{bcd}$ & $225,00 \mathrm{a}$ & $290,97 \mathrm{ab}$ \\
\hline TARUNA & $11,05 \mathrm{c}-\mathrm{g}$ & $1,67 \mathrm{c}-\mathrm{f}$ & $3,51 \mathrm{~b}-\mathrm{f}$ & $209,04 \mathrm{ab}$ & $223,06 \mathrm{abc}$ \\
\hline
\end{tabular}

\section{Analisis Korelasi}

Analisi korelasi menunjukkan hubungan antar peubah kuantitatif (Tabel 8). Nilai yang dihasilkan akan bernilai positif dan negatif. Nilai yang mendekati angka 1 menunjukkan semakin erat hubungan antar peubah (Matjik dan Sumertajaya, 2013). Nilai positif menunjukkan hubungan yang sejalan antar peubah, sedangkan nilai negatif menunjukkan sebaliknya. Peubah kuantitatif yang menunjang produksi, yaitu umur berbunga, umur panen, bobot buah, jumlah buah per tanaman, dan bobot buah pertanaman.
Hubungan umur berbunga dan umur panen memiliki nilai korelasi positif yang menunjukkan semakin cepat berbunga maka tanaman akan semakin capat berbuah dan semakin cepat panen. Umur panen berkorelasi positif dengan jumlah dan bobot buah per tanaman yan menunjukkan bahwa semakin cepat tanaman panen, potensi buah yang dihasilkan cenderung lebih banyak. Bobot buah per tanaman juga dipengaruhi oleh panjang, diameter, dan bobot per buah. Penelitian lain terkait cabai juga menunjukkan hasil yang sama bahwa bobot, diameter, dan panjang buah berpengaruh pada bobot buah per tanaman (Syukur et al., 2010).

Tabel 8. Korelasi antara karakter kuantitatif genotipe cabai

\begin{tabular}{|c|c|c|c|c|c|c|c|c|c|c|c|}
\hline & UB & UP & TTn & $\mathrm{DBt}$ & Jbeb & BSB & $\mathrm{JL}$ & $\mathrm{Pbu}$ & Dbu & Bbu & JBT \\
\hline UP & $0,585^{* *}$ & & & & & & & & & & \\
\hline TTn & $0,082 \mathrm{tn}$ & $-0,061 \mathrm{tn}$ & & & & & & & & & \\
\hline $\mathrm{DBt}$ & $0,099 \mathrm{tn}$ & $0,206 \mathrm{tn}$ & $0,506^{* * *}$ & & & & & & & & \\
\hline JBeB & $-0,270^{*}$ & $-0,353 * *$ & $0,482 * *$ & $0,075 \mathrm{tn}$ & & & & & & & \\
\hline BSB & $-0,072 \mathrm{tn}$ & $-0,210 \mathrm{tn}$ & $0,068 \mathrm{tn}$ & $0,094 \mathrm{tn}$ & $0,195 \mathrm{tn}$ & & & & & & \\
\hline JL & $0,002 \mathrm{tn}$ & $0,021 \mathrm{tn}$ & $0,096 \mathrm{tn}$ & $0,078 \mathrm{tn}$ & $0,566^{* *} *$ & 0,170 tn & & & & & \\
\hline $\mathrm{PBu}$ & $-0,220 \mathrm{tn}$ & $-0,481 * *$ & $\begin{array}{l}- \\
0,055 \mathrm{tn}\end{array}$ & $\begin{array}{l}- \\
0,057 \mathrm{tn}\end{array}$ & 0,103 th & $0,317 *$ & $-0,344 * *$ & & & & \\
\hline $\mathrm{DBu}$ & $-0,013 \mathrm{tn}$ & $0,094 \mathrm{tn}$ & $0,620 * *$ & $0,377 * *$ & $0,704 * *$ & $0,207 \mathrm{tn}$ & $0,431 * *$ & $-0,187 \mathrm{tn}$ & & & \\
\hline Bbu & $-0,157 \mathrm{tn}$ & $-0,274^{*}$ & $0,603 * *$ & $0,235 \mathrm{tn}$ & $0,794 * *$ & $0,276^{*}$ & $0,222 * *$ & $0,304^{*}$ & $0,777 * *$ & & \\
\hline JBT & $-0,598^{* *}$ & $-0,815^{* *}$ & 0,074 tn & $0,091 \mathrm{th}$ & $0,407 * *$ & $0,246 \mathrm{tn}$ & 0,010 tn & $0,439 * *$ & 0,032 tn & $0,288^{*}$ & \\
\hline BBT & $-0,535^{* *} *$ & $-0,765^{* *} *$ & $0,275^{*}$ & $0,039 \mathrm{tn}$ & $0,691 * *$ & $0,375^{* * *}$ & $0,143 \mathrm{tn}$ & $0,505^{* * *}$ & $0,372 * *$ & $0,676^{* * *}$ & $0,854 * *$ \\
\hline
\end{tabular}

Keterangan : $\quad \mathrm{UB}=$ umur berbunga, $\mathrm{UP}=$ umur panen, $\mathrm{TTn}=$ tinggi tanaman, $\mathrm{DBt}=$ diameter batang, $\mathrm{Pbu}=\mathrm{panjang}$ buah, $\mathrm{Dbu}=$ diameter buah, $\mathrm{Bbu}=$ bobot buah, $\mathrm{JL}=$ jumlah lokul, JBeB $=$ jumlah biji per buah. $\mathrm{BSB}=$ bobot $100 \mathrm{biji}, \mathrm{JBT}=$ jumlah buah per tanaman, BBT= bobot buah per tanaman, $\mathrm{tn}=$ tiak berkorelasi, $*=$ berkorelasi nyata pada taraf $5 \%, * *=$ berkorelasi nyata pada taraf $1 \%$.

\section{Analisis Gerombol}

Analisis gerombol bertujuan untuk mengelompokkan data ke dalam beberapa kelas dengan kriteria pengelompokkan berdasarkan ukuran ketidakmiripan (Yunianti et al., 2007).
Objek-objek yang memiliki kemiripan akan dibandingkan dengan kelompok lainnya (Hoft et al., 1999). Analisis gerombol dibuat berdasarkan peubah kualitatif dan peubah kuantitatif dari setiap genotipe (Gambar 1). 
Hasil yang diperoleh menunjukkan kekerabatan 19 genotipe cabai rawit terbagi ke dalam tiga gerombol besar yang dibedakan pada titik koefisien ketidakmiripan sebesar 0,3. Gerombol pertama terdiri atas CR14, Bonita, Taruna, CR8, F3, CR1, CR4, CR15, F4, CR5, CR12, CR7, CR2, CR9, CR11, dan CR 13. Gerombol kedua terdiri atas CR6 dan CR10. Gerombol ketiga terdiri atas CR3. Garis vertikal menunjukkan hubungan antar genotipe, dan garis horizontal menunjukkan nilai koefisien ketidakmiripan. Nilai koefisien ketidakmiripan yang semakin kecil menunjukkan nilai kemiripan yang semakin besar. Koefisien ketidakmiripan antara CR9 dengan CR11 memiliki nilai terkecil dibanding 19 genotipe lainnya, yaitu 0,065 dengan koefisien kemiripan 0,934. Sedangkan nilai koefisien ketidakmiripan terbesar dimiliki oleh pasangan CR10 dan CR3 dengn nilai 0,457 dengan tingkat kemiripan 0,542.

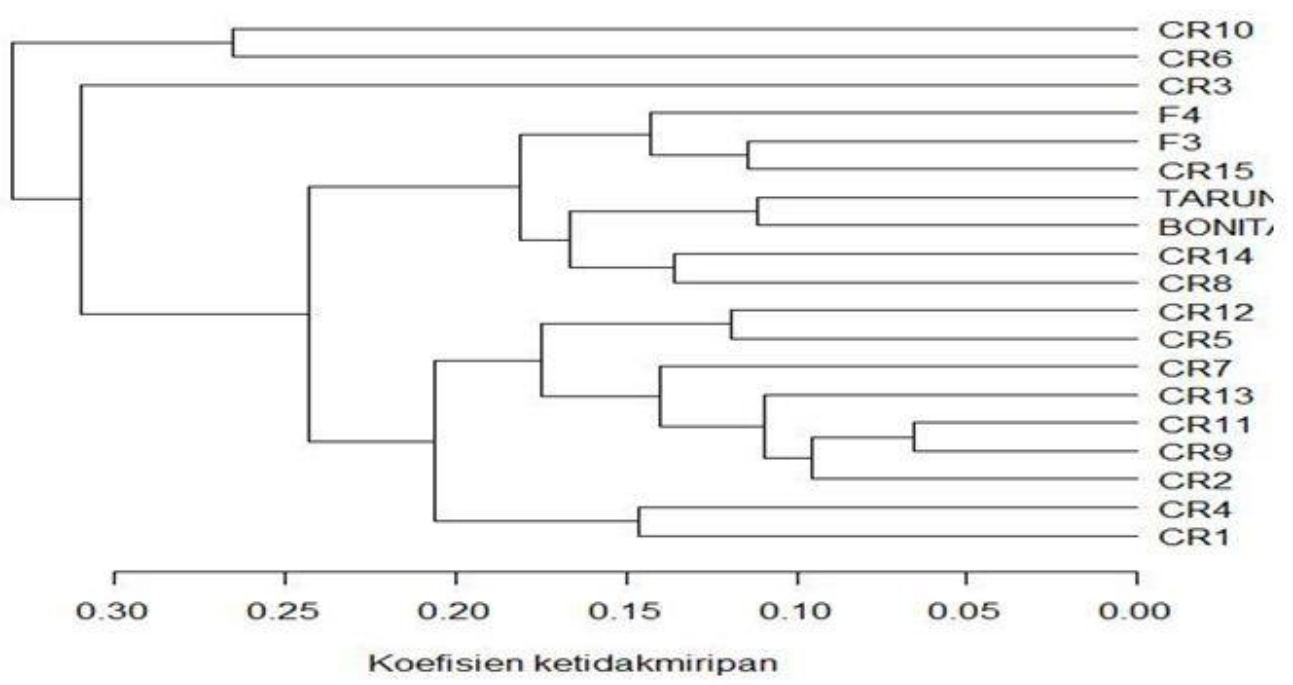

Gambar 1. Dendogram 19 genotipe cabai rawit berdasarkan karakter kualitatif dan kuantitatif

\section{KESIMPULAN}

Genotipe yang diuji menunjukkan adanya keragaman terhadap 10 peubah kualitatif dari 17 peubah kualitatif yang diuji dan memiliki pengaruh terhadap seluruh peubah kuantitatif kecuali bobot 100 biji. Hasil analisis ragam menunjukkan bahwa aksesi CR3, CR8, dan CR14 memiliki potensi hasil yang baik dan tidak berbeda nyata dengan Bonita dan Taruna sebagai genotipe pembandingnya. Hasil korelasi menunjukkan bahwa jumlah buah per tanaman memiliki korelasi positif sebesar 0,854 terhadap bobot buah per tanaman dan bobot buah per tanaman dipengaruhi secara positif oleh panjang, diameter, dan bobot per buah. Hasil analisis gerombol menunjukan bahwa CR8 dan CR14 memiliki koefisien kemiripan sebesar 0,864 dan memiliki nilai kemiripan diatas 0,800 dengan Bonita dan Taruna.

\section{DAFTAR PUSTAKA}

Acquaah, G. 2007. Principle of Plant Genetics and Breeding. Blackwell Publishing, United Kingdom.
Aprilia, I. 2014. Karakterisasi 18 genotipe terong (Solanum melongena L.) Skripsi. Institut Pertanian, Bogor.

[BI] Bank Indonesia. 2103. Pola Pembiayaan Usaha Kecil Menengah Usaha Budidaya Cabai Merah . Departemen Pengembangan Aksese Usaha dan UMKM, Jakarta.

Dhesnatama, M.A. 2016. Analisis keragaman morfologi bawang merah (Allium cepa $\mathrm{O}$. Fedisch) koleksi PKHT. Skripsi. Institut Pertanian Bogor, Bogor.

Hoft, M., S.K. Barik, A.M. Lykke 1999. Quantitative Ethnobotany: Applications of Multivariate and Statistical Analyses. UNESCO, Paris.

Gomez, K.A., A.A. Gomez. 2007. Prosedur Statistik untuk Penelitian Pertanian. UI Press, Jakarta.

[IPGRI] International Plant Genetic Resources Institute. 1995. Descriptor for capsicum (Capsicum spp.). IPGI, AVRDC, CATIE, Italia. 
Koassi, C.K., R.K. Nevry, L.Y. Guilaume, Z.N. Yesse, M. Koussemon, T. Kablan, K. Kouassi 2012. Profiles of Bioactive compounds of some pepper fruit (Capsicum L.) varieties grown in Cote d'ivore. Innovative Romanian Food Biotechnologi. 11: 23-31.

Matjik, A.A., I.M. Sumertajaya. 2013. Perancangan Percobaan dengan Aplikasi SAS dan Minitab. IPB Press, Bogor.

[Pusdatin] Pusat Data Pertanian. 2015. Outlook Bawang Merah. Pusat Data dan Sistem Pertanian, Jakarta. [Internet] [diunduh 2017 Juni 2] tersedia pada http://epublikasi.setjen.pertanian.go.id/ep ublikasi/outlook/2015/Hortikultura/Outlo ok\%20Cabai\%202015/files/assets/commo n/downloads/Outlook\%20Cabai\%202015. pdf.

Syukur, M., S. Sujiprihati, R. Yunianti, K. Nida. 2010. Pendugaan komponen ragam, heritabilitas, dan korelasi untuk menentukan kriteria seleksi cabai (Capsicum annuum L.) populasi F5. J. Hort. Indonesia. 1(2) : 74-80.

Syukur, M., S. Sujiprihati., R. Yunianti. 2012. Teknik Pemuliaan Tanaman. Penebar Swadaya, Jakarta.

Syukur, M., R. Yunianti, R. Dermawan. 2016. Budidaya Cabai Panen Setiap hari. Penebar Swadaya, Jakarta. Undang, Syukur M. Dan Sobir. 2015. Identifikasi spesies cabai rawit berdasarkan daya silang dan karakter morfologi. J. Agron. Indonesia, 43(2) : 118-125.

Yunianti, R., S. Sastrosumarjo, S. Sujiprihati, M. Surahman, S.H. Hidayat. 2007. Ketahanan 22 genotipe cabai (Capsicum spp.) terhadap Phytoptora capsici Leonian dan keragaman genotipenya. Bul. Agron. 35(2) ; 103-111. 